\title{
Mesenchymal Stem Cell-Conditioned Media Regulate Steroidogenesis and Inhibit Androgen Secretion in a PCOS Cell Model via BMP-2
}

\author{
Rishi Man Chugh ${ }^{1,2,+}$ D , Hang-soo Park ${ }^{3,+}\left(\mathbb{D}\right.$, Sahar Esfandyari ${ }^{1}$, Amro Elsharoud ${ }^{1}$, Mara Ulin ${ }^{1}$ (D) \\ and Ayman Al-Hendy ${ }^{1,3, *}$
}

1 Department of Surgery, University of Illinois at Chicago, 820 South Wood Street, Chicago, IL 60612, USA; rchugh@kumc.edu (R.M.C.); sesfan2@uic.edu (S.E.); amro.elsharoud@ttuhsc.edu (A.E.); mulin2@uic.edu (M.U.)

2 Department of Radiation Oncology, University of Kansas Medical Center, Kansas City, KS 66160, USA

3 Department of Obstetrics and Gynecology, University of Chicago, 5841 S. Maryland Ave., Chicago, IL 60637, USA; hspark06@bsd.uchicago.edu

* Correspondence: aalhendy@bsd.uchicago.edu

+ These authors contributed equally to this work.

check for updates

Citation: Chugh, R.M.; Park, H.-s.; Esfandyari, S.; Elsharoud, A.; Ulin, M.; Al-Hendy, A. Mesenchymal Stem Cell-Conditioned Media Regulate Steroidogenesis and Inhibit Androgen Secretion in a PCOS Cell Model via BMP-2. Int. J. Mol. Sci. 2021, 22, 9184. https://doi.org/ $10.3390 /$ ijms 22179184

Academic Editor: Sabrina Battista

Received: 26 July 2021

Accepted: 23 August 2021

Published: 25 August 2021

Publisher's Note: MDPI stays neutral with regard to jurisdictional claims in published maps and institutional affiliations.

Copyright: (c) 2021 by the authors. Licensee MDPI, Basel, Switzerland. This article is an open access article distributed under the terms and conditions of the Creative Commons Attribution (CC BY) license (https:/ / creativecommons.org/licenses/by/ $4.0 /)$.
Abstract: Polycystic ovary syndrome (PCOS) is the most common endocrine disorder in women. Previous studies have demonstrated the therapeutic efficacy of human bone marrow mesenchymal stem cells (BM-hMSCs) for PCOS; however, the regulatory mechanism remains unknown. Bone morphogenetic proteins (BMPs) secreted by BM-hMSCs may underlie the therapeutic effect of these cells on PCOS, based on the ability of BMPs to modulate androgen production and alter steroidogenesis pathway enzymes. In this study, we analyze the effect of BMP-2 on androgen production and steroidogenic pathway enzymes in H295R cells as a human PCOS in vitro cell model. In H295R cells, BMP-2 significantly suppressed cell proliferation, androgen production, and expression of androgen-synthesizing genes, as well as inflammatory gene expression. Furthermore, H295R cells treated with the BM-hMSCs secretome in the presence of neutralizing BMP-2 antibody or with BMP-2 gene knockdown showed augmented expression of androgen-producing genes. Taken together, these results indicate that BMP-2 is a key player mediating the favorable effects of the BM-hMSCs secretome in a human PCOS cell model. BMP-2 overexpression could increase the efficacy of BM-hMSC-based therapy, serving as a novel stem cell therapy for patients with intractable PCOS.

Keywords: mesenchymal stem cells; polycystic ovary syndrome; bone morphogenetic protein

\section{Introduction}

Polycystic ovary syndrome (PCOS) is the most common endocrine disorder in women, affecting $4-18 \%$ of reproductive-age women [1]. PCOS is characterized by chronic lowgrade inflammation and hyperandrogenism caused by excess androgen synthesis by ovarian theca cells $[2,3]$. Women with PCOS have a greater risk of developing comorbidities later in life, such as type 2 diabetes, cardiovascular diseases, and uterine cancer [4-6]. The interaction between ovarian inflammation and altered ovarian androgen synthesis in PCOS may lead to insulin resistance $[7,8]$. In several published studies, inflammatory cytokines have been shown to stimulate androgen production through upregulation of steroidogenic gene expression, such as CYP11A1, CYP17A1, and 3 $\beta$-hydroxysteroid dehydrogenase (HSD3 $\beta$ ) [9-11]. Conversely, inhibition of inflammatory pathways has been shown to reverse PCOS-induced hyperandrogenemia [12].

Previous studies have demonstrated a therapeutic effect of mesenchymal stem cells (MSCs) or their secretome (i.e., conditioned media) in various diseases, including neurological disorders [13], cardiac ischemia [14], diabetes [15], bone and cartilage diseases [16], 
liver injury or fibrosis [17], myocardial infarction, spinal cord injury, and wound healing [18]. Extensive research over the last decade has focused on the mechanisms driving the immunosuppressive and anti-inflammatory effects of bone marrow mesenchymal stem cells (BM-hMSCs) $[19,20]$. Cell-to-cell contact and secreted factors are likely to be the main mediators of these effects [21,22]. MSCs have an inherent ability to migrate toward damaged tissues [23-25], where they secrete various bioactive mediators, such as growth factors, cytokines, and extracellular vesicles that have immunosuppressive, anti-apoptotic, anti-fibrotic, angiogenic, and anti-inflammatory effects [21,26-28]. Recent studies have also demonstrated a therapeutic effect of MSCs on PCOS [29,30]. More recently, we also reported that the BM-hMSCs secretome regulates androgen production in an adrenocortical carcinoma cell line (H295R) similar to ovarian theca cells [31-33] and reverses PCOS-related conditions in a letrozole-induced PCOS mouse model [34]. In our previous study, we suggested that IL-10 secreted by BM-hMSCs induces a regulatory pathway for PCOS therapy. However, there could be more therapeutic factors secreted by BM-hMSCs in the secretome, such as cytokines, which may regulate androgen synthesis in PCOS.

Bone morphogenetic proteins (BMPs) are among the many growth factors secreted by BM-hMSCs $[35,36]$; these proteins play a key role in female fertility $[37,38]$ and are involved in all stages of folliculogenesis. BMPs are multifunctional growth factors that belong to the transforming growth factor $\beta$ (TGF $\beta$ ) superfamily $[37,39]$. Several studies have indicated a decrease in BMP levels in PCOS in both animal models and patients [40,41]. An increasing number of studies suggest that BMPs play an important role in the pathogenesis of PCOS. Theca cells in the ovary proliferate rapidly in PCOS [2,42], and BMP-2 has been shown to inhibit the proliferation of various cells in in vitro culture conditions [43-45]. In addition, there is a strong correlation between BMP-2 and BMP-4 and studies have shown that BMP-2, BMP-4, BMP-6, and BMP-7 suppress androgen secretion in bovine theca cells [46]. Together, these studies suggest that BMP-2 may reverse hyperandrogenemia in PCOS.

We hypothesize that BMP-2 secreted by BM-hMSCs drives the observed decrease in androgen production in H295R cells. Here, we show that BMP-2 treatment of H295R cells regulates cell proliferation and reduces cAMP levels and the expression of genes involved in androgen synthesis. We confirmed the effect of BMP-2 in H295R cells by neutralization of BMP-2 in the BM-hMSCs secretome. We also found decreased BMP-2 gene expression in the ovaries of a letrozole-induced PCOS mouse model. Our findings indicate that BMP-2 is a key molecule that regulates theca cell steroidogenesis in PCOS and suggest that BMP-2 may be a candidate molecule for PCOS treatment. Importantly, BMP-2 overexpressing BM-hMSCs could offer a novel stem cell-based therapy for patients with intractable PCOS.

\section{Results}

\subsection{Effect of BMP-2 on H295R Cell Proliferation and Survival}

Theca cell hyperplasia is a major finding in patients with PCOS and contributes to ovarian androgen oversecretion [2,47,48]; therefore, we evaluated the ability of BMP-2 to inhibit the proliferation of H295R cells in vitro. We found that treatment with human recombinant BMP-2 significantly decreased H295R cell proliferation in a dose- and time-dependent manner (Figure $1 \mathrm{a}-\mathrm{c}$ ). In our cell counting experiment, $24 \mathrm{~h}$ after treatment, untreated H295R cells (control) numbered $1.53 \pm 0.04 \times 10^{5}$, while other BMP-2-treated cells showed decreased cell numbers $\left(3.125 \mathrm{ng} / \mathrm{mL}: 1.47 \pm 0.04 \times 10^{5}, 6.25 \mathrm{ng} / \mathrm{mL}: 1.39 \pm 0.03 \times 10^{5}, 12.5 \mathrm{ng} / \mathrm{mL}\right.$ : $1.36 \pm 0.03 \times 10^{5}, 25 \mathrm{ng} / \mathrm{mL}: 1.29 \pm 0.01 \times 10^{5}, 50 \mathrm{ng} / \mathrm{mL}: 1.23 \pm 0.03 \times 10^{5}, 100 \mathrm{ng} / \mathrm{mL}:$ $1.15 \pm 0.06 \times 10^{5}$ ) compared to untreated H295R cells. After $72 \mathrm{~h}$, BMP-2-treated cells showed significantly decreased cell numbers $\left(3.125 \mathrm{ng} / \mathrm{mL}: 1.71 \pm 0.03 \times 10^{5}, 6.25 \mathrm{ng} / \mathrm{mL}\right.$ : $1.23 \pm 0.05 \times 10^{5}, 12.5 \mathrm{ng} / \mathrm{mL}: 1.20 \pm 0.04 \times 10^{5}, 25 \mathrm{ng} / \mathrm{mL}: 1.14 \pm 0.03 \times 10^{5}, 50 \mathrm{ng} / \mathrm{mL}:$ $\left.1.17 \pm 0.03 \times 10^{5}, 100 \mathrm{ng} / \mathrm{mL}: 1.11 \pm 0.02 \times 10^{5}\right)$ while untreated control H295R cells were proliferating well $\left(2.05 \pm 0.03 \times 10^{5}\right)$. One hundred and twenty hours after treatment, the number of untreated control H295R cells was $2.26 \pm 0.08$ and that of all of the other BMP-2-treated cells showed a dose-dependently decreased number $\left(3.125 \mathrm{ng} / \mathrm{mL}: 2.0 \pm 0.06 \times 10^{5}, 6.25 \mathrm{ng} / \mathrm{mL}\right.$ : $1.38 \pm 0.06 \times 10^{5}, 12.5 \mathrm{ng} / \mathrm{mL}: 1.18 \pm 0.09 \times 10^{5}, 25 \mathrm{ng} / \mathrm{mL}: 1.12 \pm 0.07 \times 10^{5}, 50 \mathrm{ng} / \mathrm{mL}:$ 
$\left.1.12 \pm 0.02 \times 10^{5}, 100 \mathrm{ng} / \mathrm{mL}: 1.07 \pm 0.01 \times 10^{5}\right)$. Furthermore, we found that BMP-2 treatment significantly regulates apoptosis-related gene expression (Figure $1 \mathrm{~d}$ ). Pro-apoptosis marker gene Caspase-3 expression significantly increased in BMP-2-treated H295R cells $(3.125 \mathrm{ng} / \mathrm{mL}$ : $1.39 \pm 0.04$-fold, $6.25 \mathrm{ng} / \mathrm{mL}: 1.19 \pm 0.06$-fold, $12.5 \mathrm{ng} / \mathrm{mL}: 1.25 \pm 0.06$-fold, $25 \mathrm{ng} / \mathrm{mL}$ : $1.22 \pm 0.02$-fold, $50 \mathrm{ng} / \mathrm{mL}: 1.55 \pm 0.03$-fold). On the other hand, anti-apoptosis marker gene $B C L-2$ expression was significantly downregulated by BMP-2 treatment $(3.125 \mathrm{ng} / \mathrm{mL}$ : $0.86 \pm 0.14$-fold, $6.25 \mathrm{ng} / \mathrm{mL}: 0.68 \pm 0.04$-fold, $12.5 \mathrm{ng} / \mathrm{mL}: 0.55 \pm 0.11$-fold, $25 \mathrm{ng} / \mathrm{mL}$ : $0.45 \pm 0.06$-fold, $50 \mathrm{ng} / \mathrm{mL}: 0.58 \pm 0.04$-fold). Taken together, our results indicate that BMP-2 negatively regulates $\mathrm{H} 295 \mathrm{R}$ cell proliferation indirectly by increasing apoptosis.
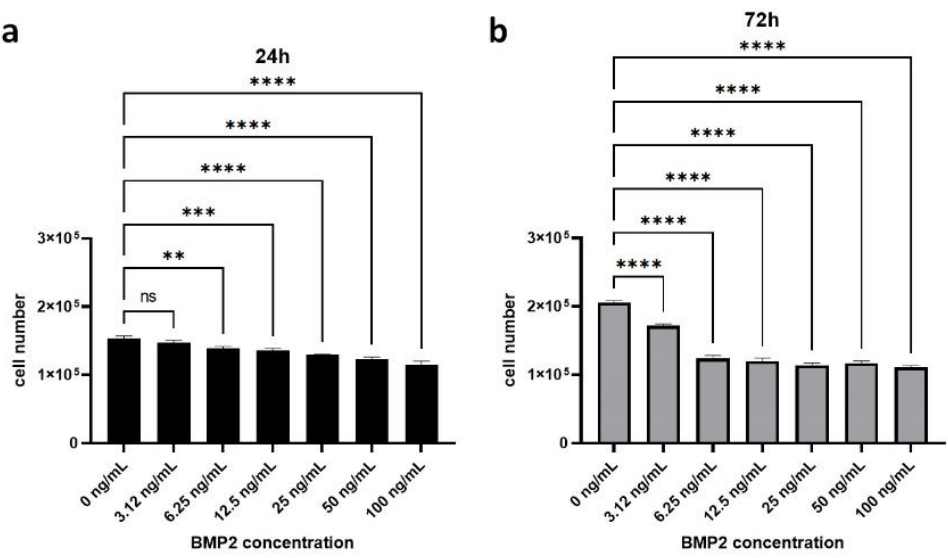

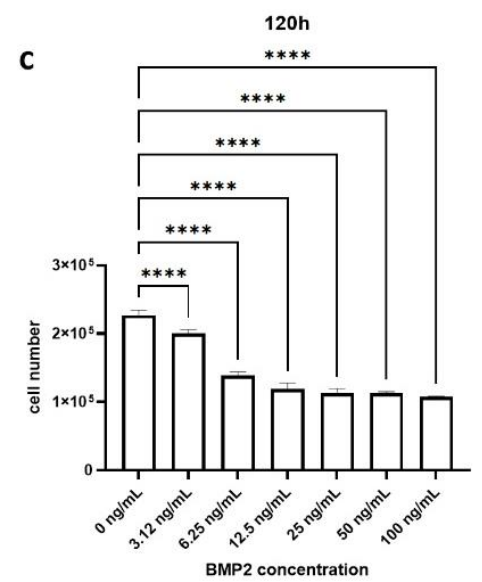

BMP2 concentration

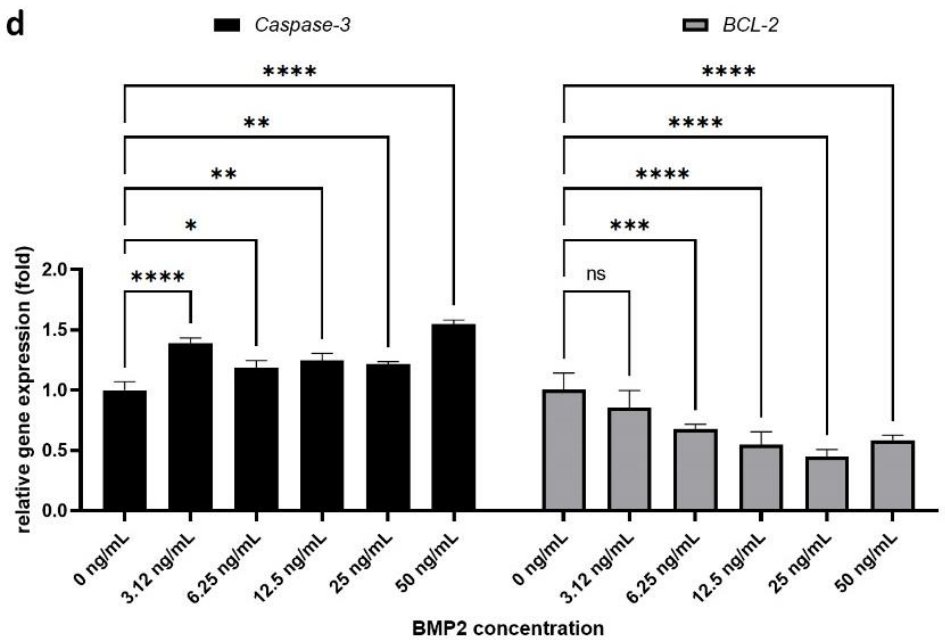

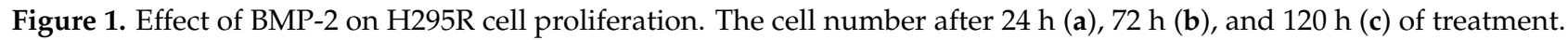
(d) Relative expression of pro-apoptosis marker gene Caspase-3 expression, and anti-apoptosis gene BCL-2 expression. Data are presented as the mean \pm SD. $\left(n=3\right.$, significance level, ${ }^{*} p<0.05,{ }^{* *} p<0.005,{ }^{* * *} p<0.0005,{ }^{* * *} p<0.0001$; ns: Not significant).

To further confirm the effect of BMP2 on H295R cell apoptosis at the protein level, we used the Western blot test. We analyzed the protein level of pro-caspase3 and cleavedcaspase3 in BMP2-treated H295R cells (Figure S1). There was no significant difference between control H295R cells and BMP2-treated H295R cells in terms of the pro-caspase level. Unfortunately, cleaved-caspase3 was not detected in our samples. We suggest that the $48 \mathrm{~h}$ treatment with BMP2 was sufficient to induce apoptosis at the mRNA level but not enough to observe a significant difference at the protein level. 


\subsection{Effect of BMP-2 on PCOS-Related Parameters in H295R Cells}

We next assessed the effect of BMP-2 on various PCOS-related parameters in H295R cells. As a first step, we analyzed androgen synthesis by H295R cells. Our RT-PCR results (Figure 2a) show that BMP-2 treatment significantly downregulated the expression of two key androgen-synthesizing enzymes, CYP17A1 $(3.125 \mathrm{ng} / \mathrm{mL}: 0.63 \pm 0.04-f o l d, 6.25 \mathrm{ng} / \mathrm{mL}$ : $0.39 \pm 0.03$-fold, $12.5 \mathrm{ng} / \mathrm{mL}: 0.70 \pm 0.04$-fold, $25 \mathrm{ng} / \mathrm{mL}: 0.49 \pm 0.05$-fold) and DENND1A ( $3.125 \mathrm{ng} / \mathrm{mL}: 0.54 \pm 0.11$-fold, $6.25 \mathrm{ng} / \mathrm{mL}: 0.50 \pm 0.04$-fold, $12.5 \mathrm{ng} / \mathrm{mL}: 0.69 \pm 0.07$-fold, $25 \mathrm{ng} / \mathrm{mL}: 0.66 \pm 0.01$-fold), but had no significant effect on CYP11A1 gene expression $(3.125 \mathrm{ng} / \mathrm{mL}: 1.19 \pm 0.11$-fold, $6.25 \mathrm{ng} / \mathrm{mL}: 0.99 \pm 0.11$-fold, $12.5 \mathrm{ng} / \mathrm{mL}: 1.57 \pm 0.04$-fold, $25 \mathrm{ng} / \mathrm{mL}: 1.04 \pm 0.01$-fold).

a

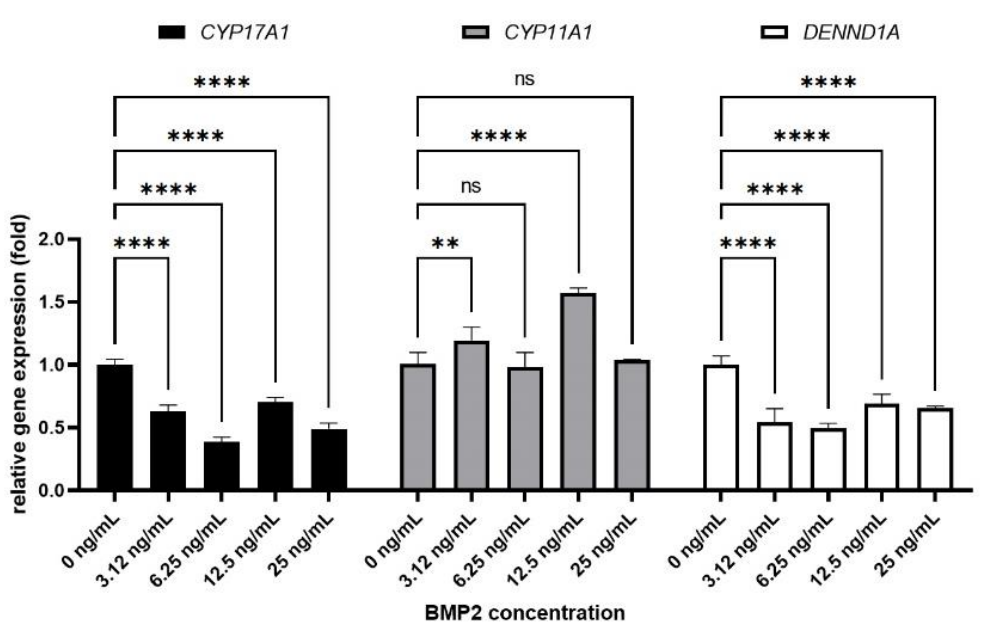

b

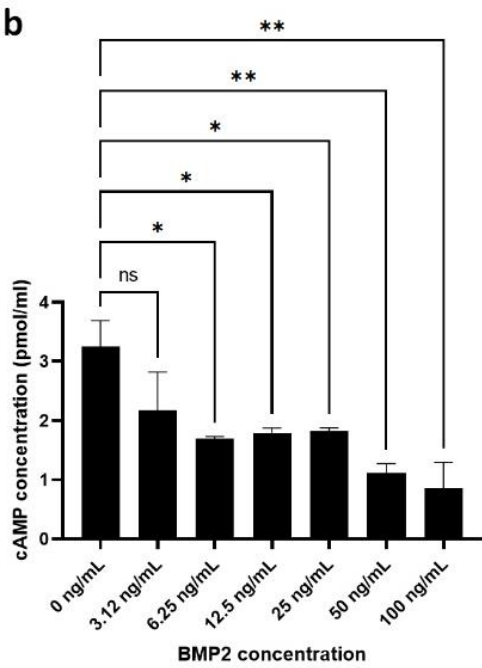

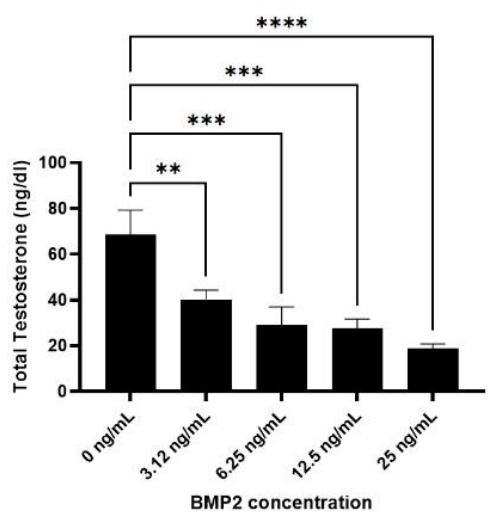

d

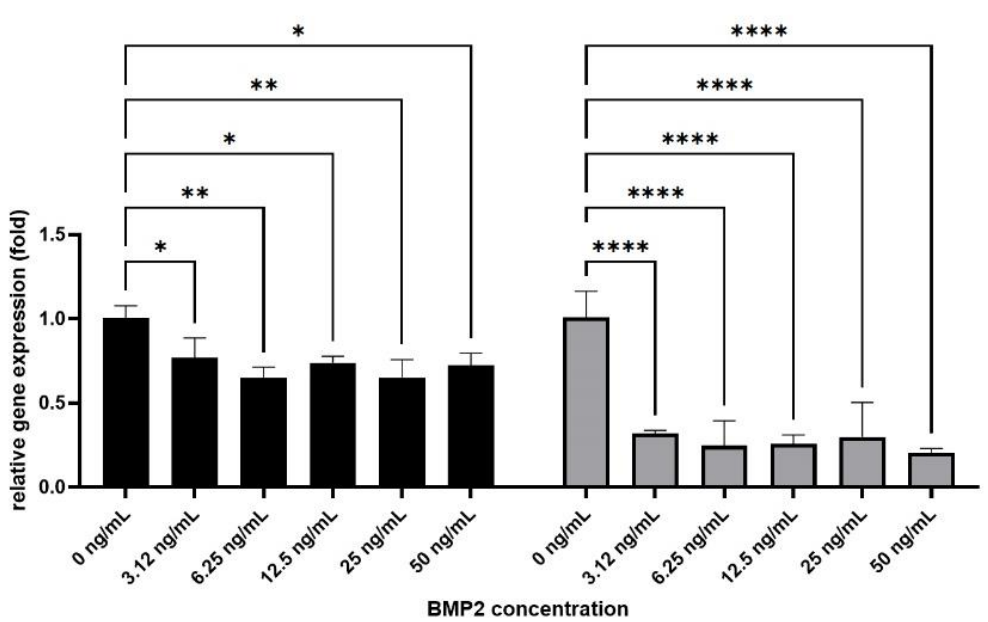

Figure 2. Effect of BMP2 on PCOS-related parameters in H295R cells. (a) Relative gene expression of CYP17A1, CYP11A1, and DENND1A in control (0 ng/mL) and BMP2-treated H295R cells (3.125 ng/mL, $6.25 \mathrm{ng} / \mathrm{mL}, 12.5 \mathrm{ng} / \mathrm{mL}, 25 \mathrm{ng} / \mathrm{mL})$. (b) The cAMP level in H295R cells after treatment with BMP-2 in control (0 ng/mL) and BMP2-treated H295R cells ( $3.125 \mathrm{ng} / \mathrm{mL}, 6.25 \mathrm{ng} / \mathrm{mL}, 12.5 \mathrm{ng} / \mathrm{mL}, 25 \mathrm{ng} / \mathrm{mL}, 50 \mathrm{ng} / \mathrm{mL}$, and $100 \mathrm{ng} / \mathrm{mL}$ ). (c) The testosterone level in H295R cells after treatment with BMP-2 in control H295R cells $(0 \mathrm{ng} / \mathrm{mL})$ and BMP2-treated H295R cells $(3.125 \mathrm{ng} / \mathrm{mL}, 6.25 \mathrm{ng} / \mathrm{mL}$, $12.5 \mathrm{ng} / \mathrm{mL}$, and $25 \mathrm{ng} / \mathrm{mL}$ ). (d) Relative expression of $I L-6$ gene expression and $I L-1 \beta$ gene expression in BMP2-treated H295R cells. Data are presented as the mean \pm SD. $(n=3$, significance level, $* p<0.05, * * p<0.005, * * * p<0.0005$, **** $p<0.0001 ;$ ns: Not significant). 
We also analyzed the protein level of steroidogenesis markers CYP17A1, CYP11A1, and DENND1A by Western blot (Figure S1). Only the DENND1A V1 protein showed decreased expression after BMP2 treatment $(0.58 \pm 0.20$-fold) compared to control H295R cells $(1.00 \pm 0.17$-fold). However, there was no significant difference between control H295R cells and BMP2-treated H295R cells. Similar to our Caspase3 protein results, the $48 \mathrm{~h}$ treatment of BMP2 was not sufficient to induce a significant effect on H295R cells at the protein level.

Next, we measured the cAMP levels in H295R cells, as the androgen synthesis cascade requires cAMP (Figure $2 \mathrm{~b}$ ). We found that BMP-2 treatment led to significant suppression of cAMP levels in H295R cells in a dose-dependent manner (control: $3.25 \pm 0.44 \mathrm{pmol} / \mathrm{mL}$ vs. $3.125 \mathrm{ng} / \mathrm{m}: 2.18 \pm 0.64 \mathrm{pmol} / \mathrm{mL}, 6.25 \mathrm{ng} / \mathrm{mL}: 1.69 \pm 0.04 \mathrm{pmol} / \mathrm{mL}, 12.5 \mathrm{ng} / \mathrm{mL}$ : $1.79 \pm 0.08 \mathrm{pmol} / \mathrm{mL}, 25 \mathrm{ng} / \mathrm{mL}: 1.82 \pm 0.05 \mathrm{pmol} / \mathrm{mL}, 50 \mathrm{ng} / \mathrm{mL}: 1.11 \pm 0.16 \mathrm{pmol} / \mathrm{mL}$, $100 \mathrm{ng} / \mathrm{mL}: 0.87 \pm 0.43 \mathrm{pmol} / \mathrm{mL}$ ).

Based on the negative effect of BMP-2 on both androgen-synthesizing enzyme expression and cAMP levels in H295R cells, we expected that BMP-2 treatment would also lead to decreased levels of androgen secretion. The total testosterone level secreted from control $\mathrm{H} 295 \mathrm{R}$ cells (untreated, $0 \mathrm{ng} / \mathrm{mL}$ of BMP2) was $68.60 \pm 10.67 \mathrm{ng} / \mathrm{dL}$. Indeed, after treatment with BMP-2, the amount of total testosterone in the culture media was significantly decreased in a dose-dependent manner $(3.125 \mathrm{ng} / \mathrm{mL}: 40.17 \pm 4.11 \mathrm{ng} / \mathrm{dL}, 6.25 \mathrm{ng} / \mathrm{mL}$ : $28.83 \pm 8.2 \mathrm{ng} / \mathrm{dL}, 12.5 \mathrm{ng} / \mathrm{mL}: 27.73 \pm 3.85 \mathrm{ng} / \mathrm{dL}, 25 \mathrm{ng} / \mathrm{mL}: 18.8 \pm 1.96 \mathrm{ng} / \mathrm{dL})$. As excess androgen secretion in PCOS is associated with chronic inflammation, we also examined the levels of inflammatory markers in H295R cells after BMP-2 treatment. We found that BMP-2 significantly suppressed the expression of both $I L-6(3.125 \mathrm{ng} / \mathrm{mL}$ : $0.76 \pm 0.12$-fold, $6.25 \mathrm{ng} / \mathrm{mL}: 0.65 \pm 0.06$-fold, $12.5 \mathrm{ng} / \mathrm{mL}: 0.73 \pm 0.04$-fold, $25 \mathrm{ng} / \mathrm{mL}$ : $0.64 \pm 0.11$-fold, $50 \mathrm{ng} / \mathrm{mL}: 0.72 \pm 0.07$-fold) and $I L-1 b$ ( $3.125 \mathrm{ng} / \mathrm{mL}: 0.32 \pm 0.02$-fold, $6.25 \mathrm{ng} / \mathrm{mL}: 0.25 \pm 0.15$-fold, $12.5 \mathrm{ng} / \mathrm{mL}: 0.26 \pm 0.05$-fold, $25 \mathrm{ng} / \mathrm{mL}: 0.30 \pm 0.20$-fold, $50 \mathrm{ng} / \mathrm{mL}: 0.20 \pm 0.03$-fold) at all tested concentrations (Figure $2 \mathrm{~d}$ ). These results support a link between androgen excess and inflammation in PCOS, and suggest that therapies that control androgen secretion may also reduce inflammation.

\subsection{Estimation of BMP-2 Secretion by BM-hMSCs}

Our previous studies revealed that the BM-hMSCs secretome regulates steroidogenesis pathway genes in H295R cells. To identify the factors in the BM-hMSCs secretome that mediate this effect, we first performed a literature search. BMP-2 emerged as a candidate factor; it is released by BM-hMSCs [49] and has been shown in various studies to control ovarian androgen levels in bovine theca cells [50]. We quantified the concentration of BMP-2 in the BM-hMSCs secretome by ELISA, using passages P3 to P5 BM-hMSCs (Figure 3a). BMP-2 secretion was highest in P3 BM-hMSCs $(150.75 \pm 1.76 \mathrm{pg} / \mathrm{mL}$ ) but was not significant between P4 $(124.5 \pm 1.78 \mathrm{pg} / \mathrm{mL})$ and P5 $(127.0 \pm 21.21 \mathrm{pg} / \mathrm{mL})$. In the following experiments, we used the P3 BM-hMSCs secretome for the treatment of H295R cells to evaluate the effect of BMP2 present in the MSC secretome.

To confirm that BMP-2 in the BM-hMSCs secretome regulates steroidogenesis in H295R cells, we neutralized BMP-2 in the BM-hMSCs secretome by an antibody-based neutralizing method. We use the neutralized secretome to treat H295R cells and analyze the expression of steroidogenesis pathway genes (Figure $3 b$ ). In our result, BM-MSCs secretome treatment of H295R cells led to decreased expression of CYP17A1 (0.64 \pm 0.04 -fold), CYP11A1 $(0.78 \pm 0.04$-fold $)$, and DENND1A (0.82 \pm 0.06 -fold) gene expression compared to control H295R cells. Interestingly, in the BMP-2-neutralized BM-hMSCs secretome-treated group, H295R cells showed a significant upregulation of androgen-synthesizing genes CYP17A1 (1.17 \pm 0.02 -fold), CYP11A1 (1.09 \pm 0.03 -fold), and DENND1A (1.30 \pm 0.10 -fold). 
a

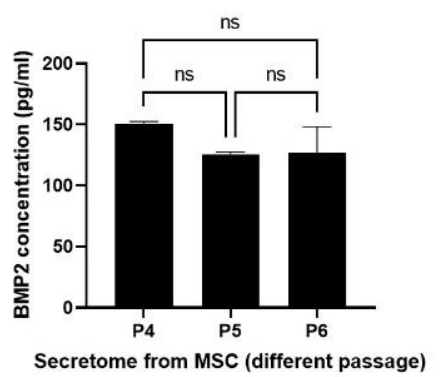

b Basal media 口 BM-hMSC CM ㅁ Neutralized BM-hMSC CM

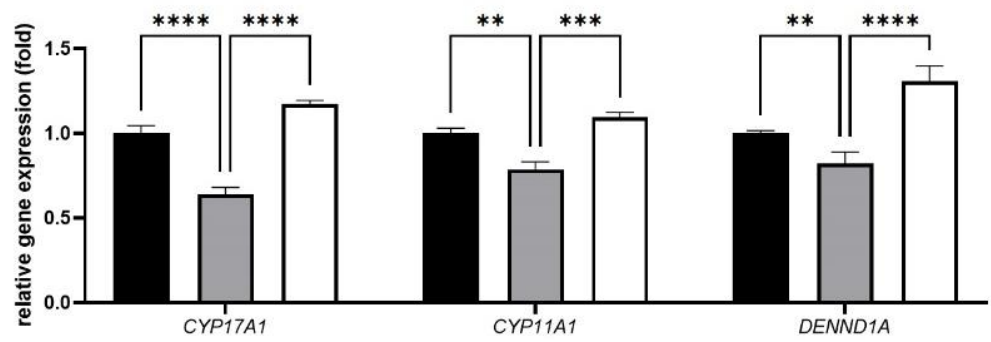

c

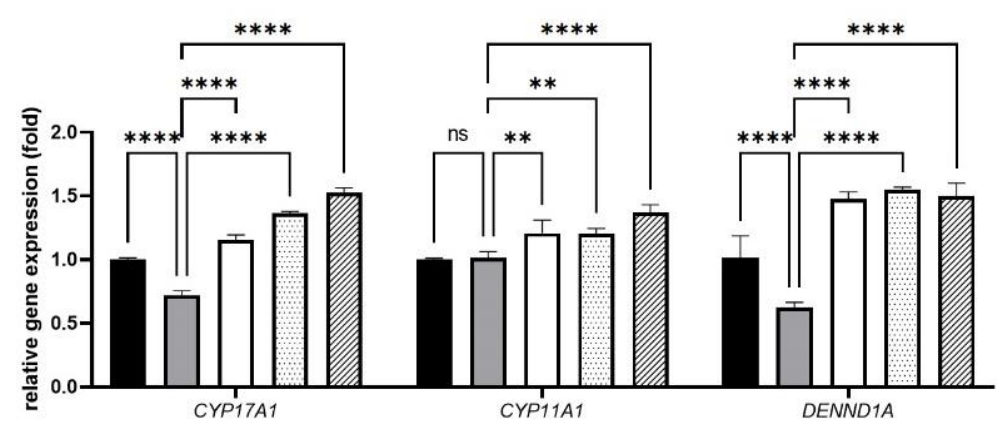

d

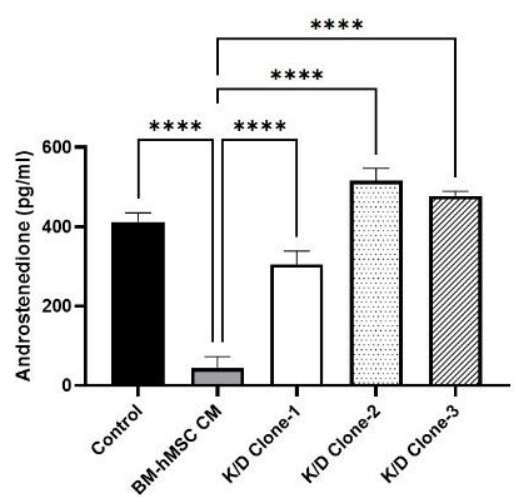

Figure 3. BMP-2 secretion in BM-hMSCs. (a) BMP-2 concentration in different passages of BM-hMSCs, P3: 150.75 \pm 1.76 , P4: $124.5 \pm 1.78, \mathrm{P} 5: 127.0 \pm 21.21$. (b) Effect of neutralized secretome on androgen synthesizing genes' (CYP17A1, CYP11A1, and DENND1A) expression. Relative gene expression in Control H295R cells (basal media), MSC conditioned media-treated H295R cells (BM-hMSC CM), and BMP2 neutralized conditioned media-treated H295R cells (Neutralized CM). (c) Effect of BMP-2 knockdown MSCs clone secretome on androgen-synthesizing genes' (CYP17A1, CYP11A1, and DENND1A) expression. (d) Effect of BMP-2 knockdown MSCs clone secretome on androstenedione synthesis. Data are presented as the mean \pm SD. ( $n=3$, significance level, ${ }^{* *} p<0.005,{ }^{* * *} p<0.0005,{ }^{* * * *} p<0.0001$; ns: Not significant.)

To further confirm the effect of BMP-2 in the BM-hMSCs secretome, we knocked down BMP-2 at the gene level using lentiviral particles followed by puromycin C selection. The secretome collected from BMP-2 knockdown BM-hMSCs (K/D clone) was used to treat H295R cells and measure the effect on androgen-synthesizing gene expression (Figure 3c). Our results show that BMP-2 knockdown nullified the suppression effect of MSC conditioned media on androgen-synthesizing genes. We found that K/D clone secretome treatment significantly upregulated the androgen-synthesizing genes CYP17A1 (Clone 1 CM: $1.16 \pm$ 0.04-fold, Clone 2 CM: $1.36 \pm$ 0.01-fold, Clone 3 CM: $1.52 \pm 0.04$-fold) and DENND1A (Clone 1 CM: $1.47 \pm 0.05$-fold, Clone $2 \mathrm{CM}$ : $1.55 \pm 0.02$-fold, Clone 3 CM: $1.50 \pm 0.10$-fold) in H295R cells compared to the wild-type BM-hMSCs secretome. CYP11A1 expression also increased in K/D clone CM-treated H295R cells (Clone 1 CM: $1.21 \pm 0.10$-fold, Clone 2 CM: $1.21 \pm 0.04$-fold, Clone 3 CM: $1.37 \pm 0.06$-fold), while there were no significant changes in the wild-type BM-hMSCs secretome-treated H295R cells $(1.01 \pm 0.05$-fold $)$. We also detected significantly higher levels of secreted androgen from H295R cells after treatment with the K/D clone CM (Clone 1 CM: $0.31 \pm 0.03$-fold, Clone 2 CM: $0.52 \pm 0.03$-fold, Clone 3 CM: $0.48 \pm 0.01$-fold) compared to the cells treated with the wild-type BM-hMSCs secretome (0.04 \pm 0.02 -fold) (Figure $3 \mathrm{~d})$ ). Together, these data confirm the role of BMP-2 as the component of the BM-hMSC secretome that regulates androgen synthesis in H295R cells as an in vitro PCOS cell model. 


\subsection{Effect of BM-hMSCs on Ovarian Tissue}

Next, we examined the therapeutic effect of BM-hMSCs in a letrozole-induced PCOS mouse model established in a previous study [51]. We injected $5 \times 10^{5} \mathrm{BM}-\mathrm{hMSC}$ per ovary and collected the ovarian tissue for histological analysis after two weeks of cell implantation. Histological analysis using $\mathrm{H}$ \& E staining revealed numerous mature follicles and corpora lutea, which represent normal ovulation, in control ovaries, while PCOS ovaries showed a lower number of antral follicles, no corpora lutea, and evidence of multiple cysts. In BM-hMSC-treated ovaries, we observed a partial restoration of corpora lutea and antral follicles, which appeared morphologically similar to those in the healthy control group (Figure 4a).

a
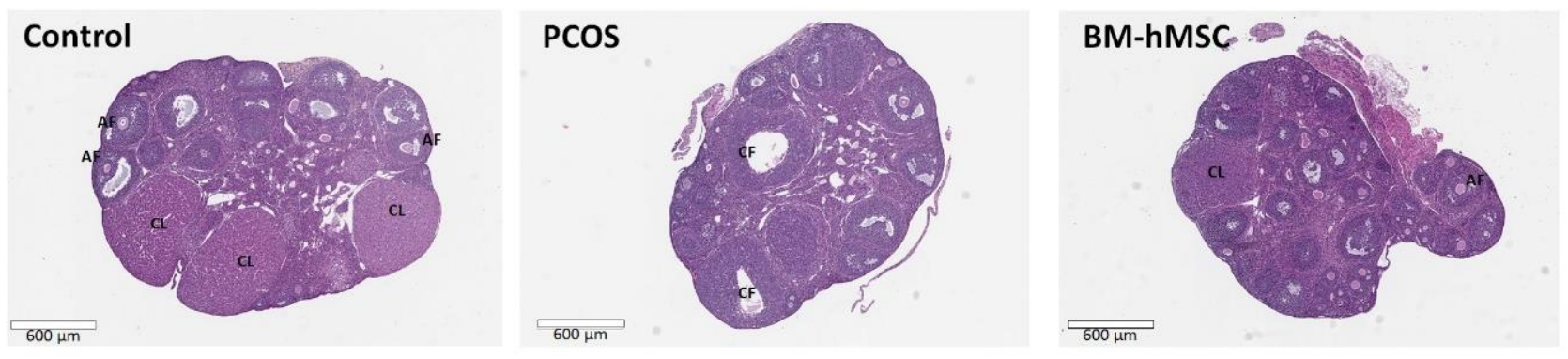

b

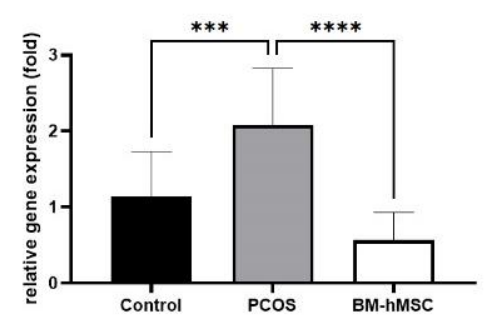

C

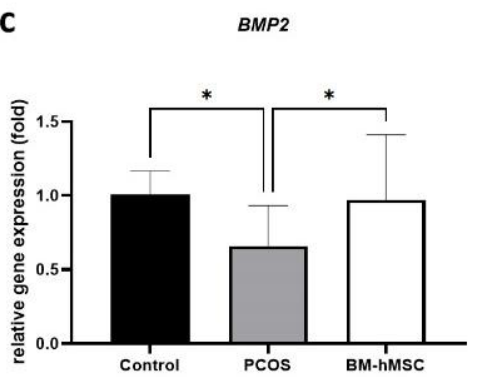

Figure 4. Effect of hBM-MSCs on ovarian tissue. (a) Morphology of ovary (H \& E staining) in healthy mouse (control), PCOS mouse (PCOS), and BM-hMSC-treated mouse (BM-hMSCs). (b) Relative expression of CYP17A1 gene in healthy mouse (control), PCOS mouse (PCOS), and BM-hMSC-treated mouse (BM-hMSCs). (c) Relative expression of BMP-2 gene in healthy mouse (control), PCOS mouse (PCOS), and BM-hMSC-treated mouse (hBM-MSCs). Data are presented as the mean \pm SD. (Number of animals $=6$ /group, significance level, ${ }^{*} p<0.05,{ }^{* * *} p<0.0005,{ }^{* * * *} p<0.0001$ ).

Next, we analyzed gene expression in the ovary tissue by quantitative RT-PCR. In PCOS mouse ovaries, CYP17A1 gene expression was significantly increased (2.08 \pm 0.48 -fold) compared to healthy control mouse ovaries (Figure $4 \mathrm{~b}$ ). In contrast, CYP17A1 gene expression in BM-hMSC-treated ovaries was significantly decreased $(0.57 \pm 0.23$-fold) compared to untreated PCOS mouse ovaries, confirming the ability of hBM-MSCs to reverse the PCOS characteristics in this mouse model. Next, we analyzed BMP2 gene expression in the mouse ovaries (Figure 4c). We found decreased BMP-2 gene expression in the PCOS mouse ovary $(0.66 \pm 0.18$-fold), which was restored after BM-hMSC treatment ( $0.97 \pm 0.28$-fold). Thus, the restoration of ovulation and normal androgen steroidogenic gene expression levels in the ovary after BM-hMSC engraftment in the letrozole-induced PCOS animal model was associated with an increase in ovarian BMP-2 expression.

\section{Discussion}

In this study, we found that BMP-2 inhibits cell proliferation and apoptosis gene expression in the H295R cell line as an in vitro model of PCOS. Moreover, BMP-2 treatment suppressed androgen secretion by decreasing the gene expression of CYP17A1 and DENND1A. We found that BMP-2 is secreted by BM-hMSCs and that depletion of BMP-2 
from the BM-hMSC secretome reverses the therapeutic effect of the secretome on reducing androgen production and inflammatory marker expression. Our in vivo data further suggest that intraovarian injection of BM-hMSC stimulates BMP2 gene expression and suppresses androgen-synthesizing gene CYP17A1 expression in the PCOS mouse ovary.

H295R cells are well-known androgen-producing cells used in many published studies $[31,52,53]$. Regulating androgen production is an important aspect of PCOS treatment because approximately half of PCOS patients show excessive adrenal androgen production $[31,52,53]$. Suppression of androgen-producing cells could thus be a main strategy to treat PCOS. In this study, we chose the dose range of BMP-2 on the basis of a previous study [43-45]. Our data showed that BMP-2 successfully inhibited H295R cell proliferation by stimulating apoptosis. BMP-2 also suppressed androgen production through the inhibition of androgen synthesis enzyme CYP17A1 and DENND1A gene expression. Taken together, our data demonstrate that BMP-2 is a promising molecule for PCOS treatment.

In this study, we reported the therapeutic benefits of BMP2. However, BMP2 is known to induce osteogenesis and chondrogenesis in MSC $[54,55]$. Due to the high osteogenic and chondrogenic potency of MSC, overexpression of BMP2 may lead to unexpected differentiation of MSC. In the case of PCOS, the intraovarian injection of MSCs, forming osteocytes or chondrocytes in the ovary, is not an ideal situation. Fortunately, endogenous expression of BMP2 did not affect their characteristics. Moreover, our study showed that a very low concentration of BMP2 $(6.25 \mathrm{ng} / \mathrm{mL})$, and even endogenous secretion by MSC $(124.5 \pm 1.78 \mathrm{pg} / \mathrm{mL})$ could suppress androgen production in H295R cells.

In a previous study, $100 \mathrm{ng} / \mathrm{mL}$ of BMP2 was used to stimulate osteogenic or chondrogenic differentiation in MSC [56,57]. Taken together, the low concentration of BMP2 used in our study is sufficient to suppress androgen production and may not induce osteogenic and chondrogenic differentiation in engrafted MSCs. In addition, we did not find any osteogenic or chondrogenic structures in our mice ovarian samples. To nullify the concerns about side effects, further in vitro and in vivo assays are needed on BMP2 overexpression to help us understand the safety issues and side effects of high-level BMP2 in MSCs.

Previous studies have reported the therapeutic potential of MSCs in various conditions such as acute lung injury (ALI), asthma, primary ovarian insufficiency (POI), and PCOS [22,58-61]. MSCs are considered an ideal cell source for cell-based therapy due to their immune suppressive potential [20]. Further studies reported that the immunosuppressive potential of MSCs led to suppressed inflammation and delayed or prevented allorejection of transplanted MSCs [62], which suggests that the immunoregulatory properties of MSCs make them an ideal cell therapeutic candidate [19]. The therapeutic effect of MSC not only relies on their differentiation property but on various secreting factors, such as cytokines and extracellular vesicles $[21,22,63]$. These secreted cytokines or therapeutic factors can regulate the abnormal status of the target cells. Based on these studies, we also reported that MSCs can be considered a bio-organ that may treat female infertility disorders [58]. Taken together, MSCs are a promising candidate as a bio-platform that secretes various therapeutic factors and could be novel options for future cell-based therapies.

In this study, we targeted PCOS, which shows hyperandrogenemia [64]. Based on previous studies, higher androgen production in women may lead to other major symptoms of PSOC such as inflammation and metabolic disorder $[9,12,65]$. In a previous study, we also demonstrated a positive feedback loop, the so-called loop of hyperandrogenemia [34], between major parameters of PCOS. It is important to regulate androgen production by androgen-producing cells, which could eventually restore fertility in PCOS patients.

We previously reported that BM-hMSCs secrete BMP-2. In our animal experiments, we injected hBM-MSCs cells as a source of BMP-2 into the ovaries of a PCOS mouse model. As expected, we found that BM-hMSCs treatment inhibited CYP17A1 gene expression in PCOS mouse ovaries compared to untreated PCOS mouse ovaries. Interestingly, BM-hMSC treatment also enhanced BMP-2 gene expression in mouse ovary tissue. This suggests that BM-hMSCs not only secrete BMP-2 but also stimulate BMP-2 gene expression in mouse ovarian tissue. 
Although we used human cells for our in vitro experiments, human and mouse BMP-2 share $92 \%$ amino acid identity [66], which may permit cross-species reactivity [67]. Previous studies reported a high probability of cytokine cross-reactivity between humans and mice at above $80 \%$ amino acid identity [66]. Therefore, it is not surprising that human BMP-2 secreted from injected BM-hMSCs could suppress androgen production and stimulate ovarian BMP-2 gene expression in a PCOS mouse model.

Our data suggest a therapeutic effect of BM-hMSC-derived BMP-2 in PCOS. MSCs secrete various factors in addition to BMP-2, including cytokines and exosomes, which can regulate cell metabolism and gene expression. Although we reported the effect of BMP-2, it may be possible that some other factors secreted by BM-hMSCs underlie their therapeutic effects in PCOS-namely, inhibition of theca cell proliferation, androgen production, and inflammatory markers. Identifying the protein profile or exosomal RNA profile of the BM-hMSC secretome might be useful to find more promising therapeutic factors to control female reproductive diseases. It is important to understand the therapeutic mechanism of BM-hMSC for further studies.

The proteomic profile of BM-hMSC secretome could help us to develop a novel approach to the treatment of PCOS. For example, it may be possible to enhance the therapeutic effect of BM-hMSCs in PCOS through overexpression of BMP-2 to downregulate ovarian androgen production. We found that the concentration of BMP-2 in the BM-hMSC secretome was much lower than in our in vitro study using recombinant BMP-2. Moreover, we reported a dose-dependent effect of BMP-2 in H295R cells for the steroidogenesis pathway. We can therefore expect a higher therapeutic effect if BM-hMSCs secrete more BMP-2. MSCs engineered to overexpress these secreted factors could be a promising future treatment option for women with intractable PCOS.

Although we reported a therapeutic effect of MSC on PCOS condition through BMP2, our study still has some limitations. Our Western blot results (Supplementary Figure S1) did not show a significant difference between control and BMP2-treated H295R cells due to the high sample-to-sample variation. In this study, we administered BMP2 to H295R cells for $48 \mathrm{~h}$. The $48 \mathrm{~h}$ treatment was sufficient to analyze mRNA level changes but not protein-level changes. Analyzing the long-term effect of BMP2 in PCOS with more samples might be an interesting topic for future study. Using MSCs from only one donor is another limitation of this study. Other MSCs isolated from different donors may show different BMP2 expression patterns. In addition, a recent study also shows that, even in the same bone marrow, MSCs show cell-to-cell variation in terms of their cytokine production [68]. To apply these findings in a clinical setting, it is important to confirm the reproducibility of the findings using multiple donor MSCs. Our in vivo data only showed morphology and mRNA expression in the ovary tissue. Due to the small size of tissue (mouse ovary), we used the whole ovary to isolate enough mRNA to check the expression of the genes. Moreover, to overcome animal-to-animal variation, we had to use all animals for RT-PCR assay. Further studies with a large sample size are needed to perform the ovarian gene expression experiment not only at the RNA level but also at the protein level.

Our study shows that the BMP-2 secreted by BM-hMSC can treat hyperandrogenemia by suppressing steroidogenesis and gene expression. Therapy using BMP-2 may represent a novel therapeutic option for women with PCOS.

\section{Materials and Methods}

\subsection{Human Mesenchymal Stem Cell Culture}

BM-hMSCs were purchased from Roosterbio (Frederick, MD, USA). These cells were originally isolated from the bone marrow of a 29-year-old female donor. For BM-hMSCs culture, around 3000 cells $/ \mathrm{cm}^{2}$ were plated in a Corning CellBIND ${ }^{\circledR} \mathrm{T} 75$ cell culture flask (Corning, NY, USA). BM-hMSCs were cultured with the recommended cell culture medium, RoosterNourish ${ }^{\mathrm{TM}}-\mathrm{MSC}-\mathrm{XF}$ (Roosterbio, Frederick, MD, USA), per the expansion protocol. When the culture reached approximately $80 \%$ confluence, cells were trypsinized using CTSTM TrypLE select enzyme (Gibco, Waltham, MA, USA) and serially expanded for two 
more passages before use in experiments. Parallel flasks were used for the collection of conditioned media (BM-hMSCs secretome). All cultured cells in this study were tested for mycoplasma using a MycoAlert ${ }^{\mathrm{TM}}$ mycoplasma detection kit (Lonza, Basel, Switzerland), and all cells cultured were free from mycoplasma contamination.

\subsection{Human Adrenocortical Carcinoma Cell Line (H295R) Culture}

H295R cells were used as an in vitro cell culture model of PCOS. H295R cells were purchased from ATCC (Manassas, VA, USA) and cultured per the recommended protocol. Briefly, H295R cells were cultured in flasks precoated with extracellular matrix (Gibco, Waltham, MA, USA) with DMEM/F12 (Gibco, Waltham, MA, USA) and 2.5\% Nu-Serum (Corning, NY, USA). Cells were subcultured at a ratio of 1:3 to 1:4 and the culture medium was changed twice a week.

\subsection{Collection of Secretome from BM-hMSCs}

Conditioned media were prepared from passage three to five BM-hMSCs. When BMMSCs cultures reached approximately 80-90\% confluence, the medium was collected from the flask and discarded. Cells were cultured with RoosterBasal ${ }^{\mathrm{TM}}-\mathrm{MSC}$ growth supplement free (Roosterbio) for $24 \mathrm{~h}$ and then conditioned media were collected from the flasks, centrifuged at $500 \times g$ for $10 \mathrm{~min}$ at $4{ }^{\circ} \mathrm{C}$ to remove the cell debris, aliquoted and stored at $-80{ }^{\circ} \mathrm{C}$ for further use. RoosterBasal ${ }^{\mathrm{TM}}-\mathrm{MSC}$ basal media without cells were also incubated for $24 \mathrm{~h}$ in a culture flask for use as a negative control.

\subsection{Treatment of H295R Cells with BMP-2}

H295R cells were cultured on six-well plates precoated with an extracellular matrix at a density of $18 \times 10^{4}$ cells per well and cultured for $48 \mathrm{~h}$. Cells were treated with 0 to $50 \mathrm{ng} / \mathrm{mL}$ recombinant human BMP-2 (R \& D Systems, Minneapolis, MN, USA) in H295R culture media for $48 \mathrm{~h}$. These concentrations were chosen based on a previous study using bovine theca cells [69]. After removal of treatment media, the cells were washed with PBS three times before adding basal media (serum-free) and incubating for another $24 \mathrm{~h}$. To compare the cell number, cells was determined using a CTSTM TrypLE select enzyme (Gibco, Waltham, MA, USA). The number of live cells was counted by Trypan blue assay, which is the most widely used and still the gold standard method to perform cell viability assays in cell culture [70,71]. Cells were collected to analyze the expression of steroidogenesis pathway genes. The cell culture supernatant was used for chemiluminescent quantification of testosterone released by H295R cells using an automated UniCel DxI 800 Access Immunoassay System (Beckman Coulter, Inc., Brea, CA, USA) [72].

\subsection{Effect of BMP-2 on H295R Cells}

After $48 \mathrm{~h}$ of treatment with different concentrations of recombinant human BMP-2, H295R cell proliferation was monitored for an additional 24, 72, and $120 \mathrm{~h}$. Markers of cell apoptosis (Caspase-3), anti-apoptosis (Bcl-2), and inflammation (IL-6 and IL-1 $\beta$ ) were examined by quantitative RT-PCR after $48 \mathrm{~h}$ of BMP-2 treatment. The cAMP level in the conditioned media was measured by ELISA (Abcam, Cambridge, MA, USA) after 48 h of BMP-2 treatment.

\subsection{ELISA for BMP-2}

To investigate the levels of BMP-2 secreted by BM-hMSCs, we measured the amount of BMP-2 in the culture media of BM-hMSCs at passages three to five by ELISA, following the manufacturer's instructions (CAT no. RAB0028, Millipore, Burlington, MA, USA). The detection limit of the ELISA kit was $45 \mathrm{pg} / \mathrm{mL}$, while the intra- and interassay coefficients of variation $(\mathrm{CV})$ were $<10 \%$ and $<12 \%$, respectively. 


\subsection{Neutralization of BMP-2 in Conditioned Media}

To confirm the role of BMP-2 in the regulation of steroidogenic gene expression in H295R cells, the BM-hMSCs secretome was incubated in six-well plates previously coated with a neutralizing antibody against human BMP-2 (Abcam, Cambridge, MA, USA) for $2 \mathrm{~h}$ at $37^{\circ} \mathrm{C}$ and under sterile conditions. After incubation, the secretome was collected and applied to H295R cells. After treatment, cells were trypsinized and collected for quantitative RT-PCR.

\subsection{Knockdown of BMP-2 in Mesenchymal Stem Cells}

BM-hMSCs were seeded onto six-well plates at a density of $8 \times 10^{4}$ cells per well and treated with human BMP-2 shRNA lentivirus (OriGene Technologies, Rockville, MD, USA) (MOI 50) at $8 \mu \mathrm{g} / \mathrm{mL}$ of polybrene per the manufacturer's protocol. After lentivirus treatment, BM-MSCs were plated at a 1:10 ratio for the selection of puromycin C-resistant colonies. Three different colonies of BM-MSCs with BMP-2 knockdown were selected and expanded for the collection of conditioned media to treat $\mathrm{H} 295 \mathrm{R}$ cells.

\subsection{Quantitative RT-PCR}

RNA isolation was performed using a TRIzol Reagent (Invitrogen, Waltham, MA, USA) according to the manufacturer's instructions. The concentration and purity of RNA were quantified by spectrophotometry at $260 \mathrm{~nm}$ using Nanodrop 2000 (Thermo Fisher Scientific, Waltham, MA, USA). One microgram of total RNA was reverse-transcribed using the RNA to cDNA EcoDry premix (Takara Bio, Kusatsu, Japan). Real-time PCR was performed using the CFX96 PCR instrument with matched primers (Table 1) and Universal SYBR Green Supermix (Bio-Rad, Hercules, CA, USA). The following PCR parameters were used: initial denaturation cycle at $95^{\circ} \mathrm{C}$ for $3 \mathrm{~min}$, followed by 40 amplification cycles at $95{ }^{\circ} \mathrm{C}$ for $10 \mathrm{~s}, 56{ }^{\circ} \mathrm{C}$ for $15 \mathrm{~s}$, and $72{ }^{\circ} \mathrm{C}$ for $1 \mathrm{~min}$. The results are presented as the fold change in relative gene expression quantified using the delta-delta $\mathrm{CT}(\Delta \Delta \mathrm{Ct})$ method. Beta-actin was used as a reference gene for sample normalization $[34,73,74]$.

Table 1. List of primers.

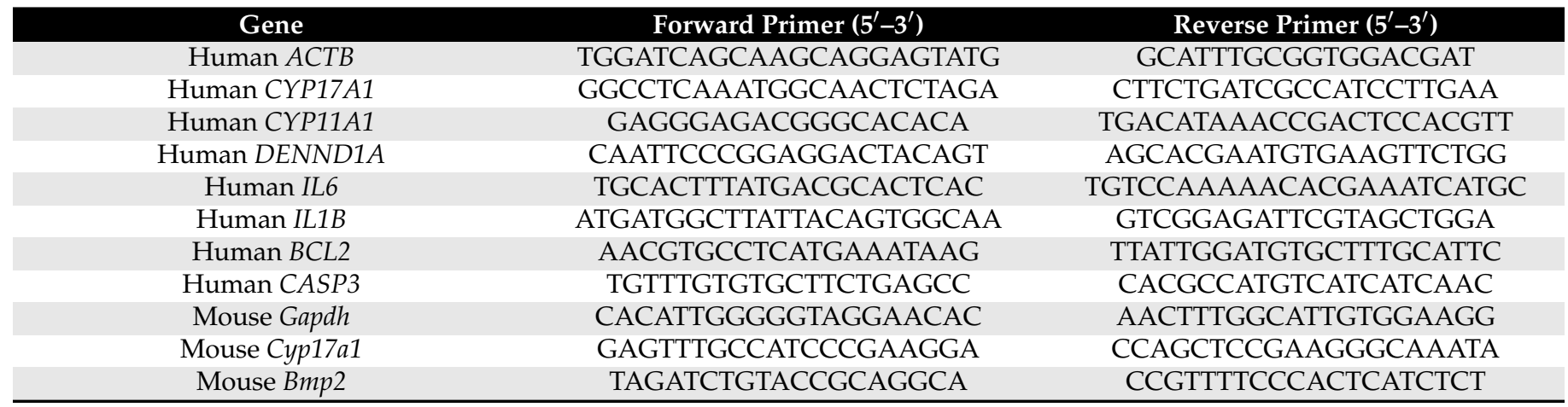

\subsection{Western Blot Analysis}

Control H295R cells and BMP-2-treated (25 ng/mL, 48 h) H295R cells were lysed with a RIPA buffer (Cell Signaling, Danvers, MA, USA) containing protease and a phosphatase inhibitor cocktail (Thermo Fisher Scientific, Waltham, MA, USA). The protein preparation and SDS-PAGE electrophoresis were performed through the protocol used in our previous study [34]. After the protein was transferred onto the PVDF membrane (Bio-Rad, Hercules, CA, USA), blocked membranes were incubated in $5 \%$ nonfat dry milk in $1 \times$ PBS overnight at $4{ }^{\circ} \mathrm{C}$ with primary antibodies against CYP17A1 (ab125022, 1:500 dilution, Abcam, Cambridge, MA, USA), CYP11A1 (ab75497, 1:500 dilution, Abcam), DENND1A (LS-C167356, 1:250, LSBio), and $\beta$-actin (clone AC-15, A5441, 1:5000, Sigma) in 1\% nonfat dry milk in $1 \mathrm{x}$ PBS overnight at $4{ }^{\circ} \mathrm{C}$. Caspase 3 was analyzed using the apoptosis Western blot cocktail antibody (ab136812, Abcam) as per the manufacturer's recommended dilution 
conditions. After washing, the membrane was incubated with the appropriate HRP-linked secondary antibodies (7076 and 7074 Cell Signaling; ab136812, Abcam) in 1\% nonfat dry milk in $1 \mathrm{x}$ PBS at room temperature for $1 \mathrm{~h}$. The membrane was developed and visualized with Trident Femto Western HRP substrate (GeneTex, Irvine, CA, USA) and ChemiDoc XRS + molecular imager (Bio-Rad). After imaging, the membranes were stripped with a RestoreTM PLUS stripping buffer (Thermo Scientific, Waltham, MA, USA) to incubate with another antibody. The signal density of each protein band was quantified using ImageJ software (U.S. National Institutes of Health, Bethesda, MD, USA) and normalized against the corresponding $\beta$-actin band.

\subsection{PCOS Mouse Model and Intra-Ovarian Injection of BM-hMSC}

Animal experiments in this study were approved by the University of Illinois at Chicago Animal Care Committee (UIC ACC). All animal experiments were performed in compliance with the University of Illinois at Chicago's policies and guidelines for use of laboratory animals. At four weeks of age, mice (Charles River, Wilmington, MA; $n=6$ /group) were subcutaneously implanted with a placebo or $5 \mathrm{mg}$ LTZ pellet (Innovative Research of America, Sarasota, FL, USA), which provides a constant release of LTZ (50 $\mathrm{\mu g} /$ day). Body weight was monitored weekly post-implantation to assess PCOS-related obesity. Five weeks after LTZ pellet implantation, mice underwent intra-ovarian injection of BM-hMSCs $\left(5 \times 10^{5}\right.$ cells / ovary) via laparotomy. For the control group and untreated PCOS group, $10 \mu \mathrm{L}$ of PBS was injected into the ovaries. Two weeks after BM-hMSCs' engraftment, mice were anesthetized and ovaries were collected for further analysis.

\subsection{Statistical Analysis}

Comparisons between groups were made by two-way ANOVA using GraphPad Prism 9 (GraphPad Software, San Diego, CA, USA). A difference between groups of $p<0.05$ was considered significant.

Supplementary Materials: The supplementary materials are available online at https:/ /www.mdpi. com/article/10.3390/ijms22179184/s1.

Author Contributions: R.M.C. and H.-s.P. were equally involved in the experimental design, performing the experiments, data analysis, and writing the manuscript. R.M.C. and S.E. participated in the cell culture and molecular experiments. H.-s.P., R.M.C., A.E. and M.U. participated in the animal experiments and tissue collection. A.A.-H. led the entire study as a corresponding author and edited the manuscript. All authors have read and agreed to the published version of the manuscript.

Funding: This research was funded by University of Illinois at Chicago, start-up fund (A.A.) and the University of Chicago start-up fund (A.A.). The APC was funded by the University of Chicago start-up fund (A.A.).

Institutional Review Board Statement: The study was conducted according to the guidelines for use of laboratory animals, and approved by the Institutional Review Board of the University of Illinois at Chicago Animal Care Committee (UIC ACC, \#18-014, first approved 3/2/2018).

Informed Consent Statement: Not applicable.

Data Availability Statement: Data is contained within the article and Supplementary Material.

Acknowledgments: This study was financially supported by start-up funds from the University of Illinois at Chicago (A.A.).

Conflicts of Interest: The authors declare that they have no competing interest.

\section{Abbreviations}

BM-hMSC Bone marrow-derived human mesenchymal stem cell

PCOS Polycystic ovary syndrome 


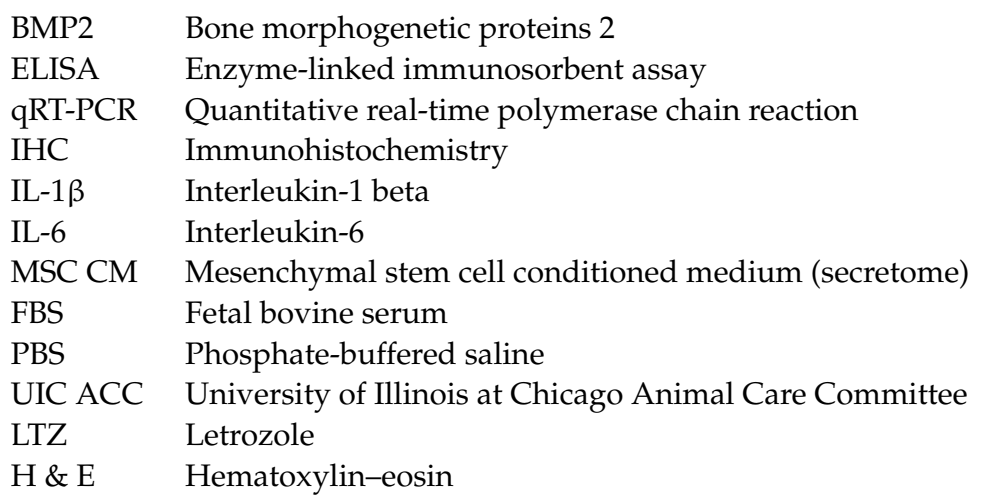

\section{References}

1. Dennett, C.C.; Simon, J. The role of polycystic ovary syndrome in reproductive and metabolic health: Overview and approaches for treatment. Diabetes Spectr. 2015, 28, 116-120. [CrossRef] [PubMed]

2. Rosenfield, R.L.; Ehrmann, D.A. The Pathogenesis of Polycystic Ovary Syndrome (PCOS): The Hypothesis of PCOS as Functional Ovarian Hyperandrogenism Revisited. Endocr. Rev. 2016, 37, 467-520. [CrossRef] [PubMed]

3. González, F. Inflammation in Polycystic Ovary Syndrome: Underpinning of insulin resistance and ovarian dysfunction. Steroids 2012, 77, 300-305. [CrossRef] [PubMed]

4. Gambineri, A.; Patton, L.; Altieri, P.; Pagotto, U.; Pizzi, C.; Manzoli, L.; Pasquali, R. Polycystic ovary syndrome is a risk factor for type 2 diabetes: Results from a long-term prospective study. Diabetes 2012, 61, 2369-2374. [CrossRef]

5. Scicchitano, P.; Dentamaro, I.; Carbonara, R.; Bulzis, G.; Dachille, A.; Caputo, P.; Riccardi, R.; Locorotondo, M.; Mandurino, C.; Matteo Ciccone, M. Cardiovascular Risk in Women With PCOS. Int. J. Endocrinol. Metab. 2012, 10, 611-618. [CrossRef]

6. Ding, D.C.; Chen, W.; Wang, J.H.; Lin, S.Z. Association between polycystic ovarian syndrome and endometrial, ovarian, and breast cancer: A population-based cohort study in Taiwan. Medicine (Baltimore) 2018, 97, e12608. [CrossRef] [PubMed]

7. de Luca, C.; Olefsky, J.M. Inflammation and insulin resistance. FEBS Lett. 2008, 582, 97-105. [CrossRef] [PubMed]

8. Corbould, A. Effects of androgens on insulin action in women: Is androgen excess a component of female metabolic syndrome? Diabetes Metab. Res. Rev. 2008, 24, 520-532. [CrossRef]

9. Fox, C.W.; Zhang, L.; Sohni, A.; Doblado, M.; Wilkinson, M.F.; Chang, R.J.; Duleba, A.J. Inflammatory Stimuli Trigger Increased Androgen Production and Shifts in Gene Expression in Theca-Interstitial Cells. Endocrinology 2019, 160, 2946-2958. [CrossRef]

10. Zhang, H.Y.; Zhu, F.F.; Zhu, Y.J.; Hu, Y.J.; Chen, X. Effects of IL-18 on the proliferation and steroidogenesis of bovine theca cells: Possible roles in the pathogenesis of polycystic ovary syndrome. J. Cell. Mol. Med. 2021, 25, 1128-1139. [CrossRef]

11. Rojas, J.; Chávez, M.; Olivar, L.; Rojas, M.; Morillo, J.; Mejías, J.; Calvo, M.; Bermúdez, V. Polycystic Ovary Syndrome, Insulin Resistance, and Obesity: Navigating the Pathophysiologic Labyrinth. Int. J. Reprod. Med. 2014, 2014, 719050. [CrossRef]

12. Lang, Q.; Yidong, X.; Xueguang, Z.; Sixian, W.; Wenming, X.; Tao, Z. ETA-mediated anti-TNF- $\alpha$ therapy ameliorates the phenotype of PCOS model induced by letrozole. PLoS ONE 2019, 14, e0217495. [CrossRef]

13. Momin, E.N.; Mohyeldin, A.; Zaidi, H.A.; Vela, G.; Quiñones-Hinojosa, A. Mesenchymal stem cells: New approaches for the treatment of neurological diseases. Curr. Stem Cell Res. Ther. 2010, 5, 326-344. [CrossRef] [PubMed]

14. Jeong, H.; Yim, H.W.; Park, H.J.; Cho, Y.; Hong, H.; Kim, N.J.; Oh, I.H. Mesenchymal Stem Cell Therapy for Ischemic Heart Disease: Systematic Review and Meta-analysis. Int. J. Stem Cells 2018, 11, 1-12. [CrossRef] [PubMed]

15. Moreira, A.; Kahlenberg, S.; Hornsby, P. Therapeutic potential of mesenchymal stem cells for diabetes. J. Mol. Endocrinol. 2017, 59, R109-R120. [CrossRef]

16. Zhang, R.; Ma, J.; Han, J.; Zhang, W.; Ma, J. Mesenchymal stem cell related therapies for cartilage lesions and osteoarthritis. Am. J. Transl. Res. 2019, 11, 6275-6289.

17. Driscoll, J.; Patel, T. The mesenchymal stem cell secretome as an acellular regenerative therapy for liver disease. J. Gastroenterol. 2019, 54, 763-773. [CrossRef] [PubMed]

18. Vizoso, F.J.; Eiro, N.; Cid, S.; Schneider, J.; Perez-Fernandez, R. Mesenchymal Stem Cell Secretome: Toward Cell-Free Therapeutic Strategies in Regenerative Medicine. Int. J. Mol. Sci. 2017, 18, 1852. [CrossRef]

19. Han, Y.; Li, X.; Zhang, Y.; Han, Y.; Chang, F.; Ding, J. Mesenchymal Stem Cells for Regenerative Medicine. Cells 2019, 8, 886. [CrossRef]

20. Zhang, J.; Huang, X.; Wang, H.; Liu, X.; Zhang, T.; Wang, Y.; Hu, D. The challenges and promises of allogeneic mesenchymal stem cells for use as a cell-based therapy. Stem Cell Res. Ther. 2015, 6, 234. [CrossRef] [PubMed]

21. Fan, X.-L.; Zhang, Y.; Li, X.; Fu, Q.-L. Mechanisms underlying the protective effects of mesenchymal stem cell-based therapy. Cell Mol. Life Sci. 2020, 77, 2771-2794. [CrossRef] [PubMed]

22. Harrell, C.R.; Fellabaum, C.; Jovicic, N.; Djonov, V.; Arsenijevic, N.; Volarevic, V. Molecular Mechanisms Responsible for Therapeutic Potential of Mesenchymal Stem Cell-Derived Secretome. Cells 2019, 8, 467. [CrossRef] 
23. Chapel, A.; Bertho, J.M.; Bensidhoum, M.; Fouillard, L.; Young, R.G.; Frick, J.; Demarquay, C.; Cuvelier, F.; Mathieu, E.; Trompier, F.; et al. Mesenchymal stem cells home to injured tissues when co-infused with hematopoietic cells to treat a radiation-induced multi-organ failure syndrome. J. Gene Med. 2003, 5, 1028-1038. [CrossRef] [PubMed]

24. Caplan, A.I. Why are MSCs therapeutic? New data: New insight. J. Pathol. 2009, 217, 318-324. [CrossRef]

25. Ullah, M.; Liu, D.D.; Thakor, A.S. Mesenchymal Stromal Cell Homing: Mechanisms and Strategies for Improvement. iScience 2019, 15, 421-438. [CrossRef]

26. Salgado, A.J.; Reis, R.L.; Sousa, N.J.; Gimble, J.M. Adipose tissue derived stem cells secretome: Soluble factors and their roles in regenerative medicine. Curr. Stem Cell Res. Ther. 2010, 5, 103-110. [CrossRef]

27. Sun, D.Z.; Abelson, B.; Babbar, P.; Damaser, M.S. Harnessing the mesenchymal stem cell secretome for regenerative urology. Nat. Rev. Urol. 2019, 16, 363-375. [CrossRef] [PubMed]

28. Hmadcha, A.; Martin-Montalvo, A.; Gauthier, B.R.; Soria, B.; Capilla-Gonzalez, V. Therapeutic Potential of Mesenchymal Stem Cells for Cancer Therapy. Front. Bioeng. Biotechnol. 2020, 8, 43. [CrossRef] [PubMed]

29. Xie, Q.; Xiong, X.; Xiao, N.; He, K.; Chen, M.; Peng, J.; Su, X.; Mei, H.; Dai, Y.; Wei, D.; et al. Mesenchymal Stem Cells Alleviate DHEA-Induced Polycystic Ovary Syndrome (PCOS) by Inhibiting Inflammation in Mice. Stem Cells Int. 2019, 2019, 9782373. [CrossRef]

30. Kalhori, Z.; Azadbakht, M.; Soleimani Mehranjani, M.; Shariatzadeh, M.A. Improvement of the folliculogenesis by transplantation of bone marrow mesenchymal stromal cells in mice with induced polycystic ovary syndrome. Cytotherapy 2018, 20, 1445-1458 [CrossRef] [PubMed]

31. Marti, N.; Bouchoucha, N.; Sauter, K.S.; Flück, C.E. Resveratrol inhibits androgen production of human adrenocortical H295R cells by lowering CYP17 and CYP21 expression and activities. PLoS ONE 2017, 12, e0174224. [CrossRef]

32. Kempná, P.; Hofer, G.; Mullis, P.E.; Flück, C.E. Pioglitazone inhibits androgen production in NCI-H295R cells by regulating gene expression of CYP17 and HSD3B2. Mol. Pharmacol. 2007, 71, 787-798. [CrossRef] [PubMed]

33. Kumar, A.; Magoffin, D.; Munir, I.; Azziz, R. Effect of insulin and testosterone on androgen production and transcription of SULT2A1 in the NCI-H295R adrenocortical cell line. Fertil. Steril. 2009, 92, 793-797. [CrossRef]

34. Chugh, R.M.; Park, H.S.; El Andaloussi, A.; Elsharoud, A.; Esfandyari, S.; Ulin, M.; Bakir, L.; Aboalsoud, A.; Ali, M.; Ashour, D.; et al. Mesenchymal stem cell therapy ameliorates metabolic dysfunction and restores fertility in a PCOS mouse model through interleukin-10. Stem Cell Res. Ther. 2021, 12, 388. [CrossRef]

35. Dilogo, I.H.; Fiolin, J.; Aprianto, P. Osteogenic Potency of Secretome Bone Marrow Derived Mesenchymal Stem Cells: A Literature Review. Adv. Sci. Lett. 2018, 24, 6206-6208. [CrossRef]

36. Polacek, M.; Bruun, J.A.; Elvenes, J.; Figenschau, Y.; Martinez, I. The secretory profiles of cultured human articular chondrocytes and mesenchymal stem cells: Implications for autologous cell transplantation strategies. Cell Transpl. 2011, 20, 1381-1393. [CrossRef]

37. Yoshino, O.; Shi, J.; Osuga, Y.; Harada, M.; Nishii, O.; Yano, T.; Taketani, Y. The function of bone morphogenetic proteins in the human ovary. Reprod. Med. Biol. 2011, 10, 1-7. [CrossRef]

38. Hashimoto, O.; Moore, R.K.; Shimasaki, S. Posttranslational processing of mouse and human BMP-15: Potential implication in the determination of ovulation quota. Proc. Natl. Acad. Sci. USA 2005, 102, 5426-5431. [CrossRef]

39. Otsuka, F.; Inagaki, K. Unique bioactivities of bone morphogenetic proteins in regulation of reproductive endocrine functions. Reprod. Med. Biol. 2011, 10, 131-142. [CrossRef] [PubMed]

40. van Houten, E.L.; Laven, J.S.; Louwers, Y.V.; McLuskey, A.; Themmen, A.P.; Visser, J.A. Bone morphogenetic proteins and the polycystic ovary syndrome. J. Ovarian. Res. 2013, 6, 32. [CrossRef] [PubMed]

41. Xu, N.; Kwon, S.; Abbott, D.H.; Geller, D.H.; Dumesic, D.A.; Azziz, R.; Guo, X.; Goodarzi, M.O. Epigenetic mechanism underlying the development of polycystic ovary syndrome (PCOS)-like phenotypes in prenatally androgenized rhesus monkeys. PLoS ONE 2011, 6, e27286. [CrossRef]

42. Bremer, A.A. Polycystic Ovary Syndrome in the Pediatric Population. Metab. Syndr. Relat. Disord. 2010, 8, 375-394. [CrossRef]

43. Hardwick, J.C.H.; Van Den Brink, G.R.; Bleuming, S.A.; Ballester, I.; Van Den Brande, J.M.H.; Keller, J.J.; Offerhaus, G.J.A.; Van Deventer, S.J.H.; Peppelenbosch, M.P. Bone morphogenetic protein 2 is expressed by, and acts upon, mature epithelial cells in the colon. Gastroenterology 2004, 126, 111-121. [CrossRef]

44. Chen, A.; Wang, D.; Liu, X.; He, S.; Yu, Z.; Wang, J. Inhibitory effect of BMP-2 on the proliferation of breast cancer cells. Mol. Med. Rep. 2012, 6, 615-620. [CrossRef]

45. Zhang, J.; Ge, Y.; Sun, L.; Cao, J.; Wu, Q.; Guo, L.; Wang, Z. Effect of bone morphogenetic protein-2 on proliferation and apoptosis of gastric cancer cells. Int. J. Med. Sci. 2012, 9, 184-192. [CrossRef]

46. Glister, C.; Satchell, L.; Bathgate, R.A.D.; Wade, J.D.; Dai, Y.; Ivell, R.; Anand-Ivell, R.; Rodgers, R.J.; Knight, P.G. Functional link between bone morphogenetic proteins and insulin-like peptide 3 signaling in modulating ovarian androgen production. Proc. Natl. Acad. Sci. USA 2013, 110, E1426-E1435. [CrossRef] [PubMed]

47. Ma, Y.; Andrisse, S.; Chen, Y.; Childress, S.; Xue, P.; Wang, Z.; Jones, D.; Ko, C.; Divall, S.; Wu, S. Androgen Receptor in the Ovary Theca Cells Plays a Critical Role in Androgen-Induced Reproductive Dysfunction. Endocrinology 2017, 158, 98-108. [CrossRef] [PubMed]

48. Richards, J.S.; Ren, Y.A.; Candelaria, N.; Adams, J.E.; Rajkovic, A. Ovarian Follicular Theca Cell Recruitment, Differentiation, and Impact on Fertility: 2017 Update. Endocr. Rev. 2018, 39, 1-20. [CrossRef] 
49. Paul, D.; Samuel, S.M.; Maulik, N. Mesenchymal stem cell: Present challenges and prospective cellular cardiomyoplasty approaches for myocardial regeneration. Antioxid. Redox Signal. 2009, 11, 1841-1855. [CrossRef] [PubMed]

50. Laird, M.; Glister, C.; Cheewasopit, W.; Satchell, L.S.; Bicknell, A.B.; Knight, P.G. 'Free' inhibin alpha subunit is expressed by bovine ovarian theca cells and its knockdown suppresses androgen production. Sci. Rep. 2019, 9, 19793. [CrossRef] [PubMed]

51. Kauffman, A.S.; Thackray, V.G.; Ryan, G.E.; Tolson, K.P.; Glidewell-Kenney, C.A.; Semaan, S.J.; Poling, M.C.; Iwata, N.; Breen, K.M.; Duleba, A.J.; et al. A Novel Letrozole Model Recapitulates Both the Reproductive and Metabolic Phenotypes of Polycystic Ovary Syndrome in Female Mice. Biol. Reprod. 2015, 93, 69. [CrossRef] [PubMed]

52. Hecker, M.; Newsted, J.L.; Murphy, M.B.; Higley, E.B.; Jones, P.D.; Wu, R.; Giesy, J.P. Human adrenocarcinoma (H295R) cells for rapid in vitro determination of effects on steroidogenesis: Hormone production. Toxicol. Appl. Pharmacol. 2006, 217, 114-124. [CrossRef]

53. McAllister, J.M.; Han, A.X.; Modi, B.P.; Teves, M.E.; Mavodza, G.R.; Anderson, Z.L.; Shen, T.; Christenson, L.K.; Archer, K.J.; Strauss, J.F. miRNA Profiling Reveals miRNA-130b-3p Mediates DENND1A Variant 2 Expression and Androgen Biosynthesis. Endocrinology 2019, 160, 1964-1981. [CrossRef] [PubMed]

54. Liang, Z.; Luo, Y.; Lv, Y. Mesenchymal stem cell-derived microvesicles mediate BMP2 gene delivery and enhance bone regeneration. J. Mater. Chem. B 2020, 8, 6378-6389. [CrossRef] [PubMed]

55. Osyczka, A.M.; Diefenderfer, D.L.; Bhargave, G.; Leboy, P.S. Different effects of BMP-2 on marrow stromal cells from human and rat bone. Cells Tissues Organs 2004, 176, 109-119. [CrossRef] [PubMed]

56. Marupanthorn, K.; Tantrawatpan, C.; Kheolamai, P.; Tantikanlayaporn, D.; Manochantr, S. Bone morphogenetic protein-2 enhances the osteogenic differentiation capacity of mesenchymal stromal cells derived from human bone marrow and umbilical cord. Int. J. Mol. Med. 2017, 39, 654-662. [CrossRef]

57. Noth, U.; Rackwitz, L.; Heymer, A.; Weber, M.; Baumann, B.; Steinert, A.; Schutze, N.; Jakob, F.; Eulert, J. Chondrogenic differentiation of human mesenchymal stem cells in collagen type I hydrogels. J. Biomed. Mater. Res. A 2007, 83, 626-635. [CrossRef]

58. Esfandyari, S.; Chugh, R.M.; Park, H.S.; Hobeika, E.; Ulin, M.; Al-Hendy, A. Mesenchymal Stem Cells as a Bio Organ for Treatment of Female Infertility. Cells 2020, 9, 2253. [CrossRef]

59. Park, K.S.; Bandeira, E.; Shelke, G.V.; Lasser, C.; Lotvall, J. Enhancement of therapeutic potential of mesenchymal stem cell-derived extracellular vesicles. Stem Cell Res. Ther. 2019, 10, 288. [CrossRef]

60. Patel, D.M.; Shah, J.; Srivastava, A.S. Therapeutic potential of mesenchymal stem cells in regenerative medicine. Stem Cells Int. 2013, 2013, 496218. [CrossRef]

61. Satija, N.K.; Singh, V.K.; Verma, Y.K.; Gupta, P.; Sharma, S.; Afrin, F.; Sharma, M.; Sharma, P.; Tripathi, R.P.; Gurudutta, G.U. Mesenchymal stem cell-based therapy: A new paradigm in regenerative medicine. J. Cell Mol. Med. 2009, 13, 4385-4402. [CrossRef]

62. Ankrum, J.A.; Ong, J.F.; Karp, J.M. Mesenchymal stem cells: Immune evasive, not immune privileged. Nat. Biotechnol. 2014, 32, 252-260. [CrossRef]

63. Zheng, G.; Huang, R.; Qiu, G.; Ge, M.; Wang, J.; Shu, Q.; Xu, J. Mesenchymal stromal cell-derived extracellular vesicles: Regenerative and immunomodulatory effects and potential applications in sepsis. Cell Tissue Res. 2018, 374, 1-15. [CrossRef]

64. Fauser, B.C.; Tarlatzis, B.C.; Rebar, R.W.; Legro, R.S.; Balen, A.H.; Lobo, R.; Carmina, E.; Chang, J.; Yildiz, B.O.; Laven, J.S.; et al. Consensus on women's health aspects of polycystic ovary syndrome (PCOS): The Amsterdam ESHRE/ASRM-Sponsored 3rd PCOS Consensus Workshop Group. Fertil. Steril. 2012, 97, 28-38.e25. [CrossRef] [PubMed]

65. Gonzalez, F.; Sia, C.L.; Bearson, D.M.; Blair, H.E. Hyperandrogenism induces a proinflammatory TNFalpha response to glucose ingestion in a receptor-dependent fashion. J. Clin. Endocrinol. Metab. 2014, 99, E848-E854. [CrossRef] [PubMed]

66. Scheerlinck, J.-P.Y. Cytokine Species-Specificity and Humanized Mice. In Humanized Mice for HIV Research; Poluektova, L.Y., Garcia, J.V., Koyanagi, Y., Manz, M.G., Tager, A.M., Eds.; Springer: New York, NY, USA, 2014; pp. 93-108.

67. Scheerlinck, J.P. Functional and structural comparison of cytokines in different species. Vet. Immunol. Immunopathol. 1999, 72, 39-44. [CrossRef]

68. O'Connor, K.C. Molecular Profiles of Cell-to-Cell Variation in the Regenerative Potential of Mesenchymal Stromal Cells. Stem Cells Int. 2019, 2019, 5924878. [CrossRef]

69. Glister, C.; Richards, S.L.; Knight, P.G. Bone Morphogenetic Proteins (BMP)-4, -6, and -7 Potently Suppress Basal and Luteinizing Hormone-Induced Androgen Production by Bovine Theca Interna Cells in Primary Culture: Could Ovarian Hyperandrogenic Dysfunction Be Caused by a Defect in Thecal BMP Signaling? Endocrinology 2005, 146, 1883-1892. [CrossRef]

70. Crowley, L.C.; Marfell, B.J.; Christensen, M.E.; Waterhouse, N.J. Measuring Cell Death by Trypan Blue Uptake and Light Microscopy. Cold Spring Harb. Protoc. 2016, 2016. [CrossRef]

71. Piccinini, F.; Tesei, A.; Arienti, C.; Bevilacqua, A. Cell Counting and Viability Assessment of 2D and 3D Cell Cultures: Expected Reliability of the Trypan Blue Assay. Biol. Proced. Online 2017, 19, 8. [CrossRef]

72. Hernandez, N.; Mauri, M.; Alfayate, R.; Torregrosa, M.E.; Chinchilla, V. A fifty-one-year-old woman with raised testosterone concentration. Endocrinol. Nutr. 2011, 58, 50-51. [CrossRef] [PubMed]

73. Lin, Z.S.; Chu, H.C.; Yen, Y.C.; Lewis, B.C.; Chen, Y.W. Kruppel-like factor 4, a tumor suppressor in hepatocellular carcinoma cells reverts epithelial mesenchymal transition by suppressing slug expression. PLoS ONE 2012, 7, e43593. [CrossRef] [PubMed]

74. Sumimoto, H.; Takano, A.; Teramoto, K.; Daigo, Y. RAS-Mitogen-Activated Protein Kinase Signal Is Required for Enhanced PD-L1 Expression in Human Lung Cancers. PLoS ONE 2016, 11, e0166626. [CrossRef] [PubMed] 